того, без инвестиционных накоплений и соответствующих материальных ресурсов в инвестировании вообще никаких положительных сдвигов не происходит.

Без инвестиций невозможны современное создание капитала, обеспечение конкурентоспособности товаропроизводителей на внешних и внутренних рынках.

Процессы структурного и качественного обновления мирового товаропроизводства и рыночной инфраструктуры происходят исключительно путем и за счет инвестирования. Чем интенсивней оно осуществляется, тем быстрее происходит воспроизводственный процесс, тем активнее происходят эффективные рыночные преобразования.

\begin{tabular}{l} 
*** \\
1. http://www.kapital-rus.ru - интернет-журнал «Капитал страны» - журнал об инвестиционных \\
возможностях Рoсcии \\
2. http://www.kommersant.ru - интернет-журнал «Коммерсант» \\
3. http://www.b2russia.ru - интернет-портал об инвестициях \\
\hline
\end{tabular}

\title{
Саратова К.И.
}

Современная банковская система России: проблемы, перспективы развития

Институт сферы обслужсивания и предпринимательства (филиал) ФГБОУ ВПО «Донской государственный технический университет»

(Россия, Шахты)

doi:10.18411/lj-11-2018-53

idsp: ljournal-11-2018-53

\section{Аннотация}

Статья посвящена вопросам современного состояния Российской банковской системы, проведен анализ макроэкономических показателей банковского сектора, выявлены и озвучены проблемы развития банковской системы в условиях экономической нестабильности, выбраны основные направления развития банковской системы.

Ключевые слова: банковская система, банковский сектор, центральный банк, кредитные организации, макроэкономические показатели.

Устойчивый рост национальной экономики может быть обеспечен при условии существования стабильной и эффективной банковской системы. Однако стабильность банковской системы зависит от объективного ряда факторов в их числе: степень экономического развития страны; макроэкономическая ситуация складывающаяся в стране в настоящее время; состояние денежной системы страны и платежеспособность ее экономических субъектов; приверженность населения страны к сбережениям и т.п. В связи с этим прослеживается определенная взаимосвязь между показателями стабильности банковской системы и общими показателями состояния экономики страны в целом, что свидетельствует о взаимном влиянии данных институтов.

Для определения тенденций развития и выявления негативных факторов, оказывающих существенное влияние на российскую банковскую систему, а так же для эффективного планирования и прогнозирования дальнейшей экономической стратегии, целесообразно исследовать динамику показателей эффективности банковской системы, а изучив, определить дальнейшую интеграцию банковского сектора в экономику страны.[1]

Важными показателями характеризующими стабильность банковской системы, являются прежде всего такие, как:

- насыщенность экономики банковскими кредитами (кредиты/ВВП в \%);

- насыщенность банковскими активами (активы/ВВП в \%);

- насыщенность банковскими депозитами (депозиты/ВВП в \%);

— отношение собственных средств (капитала) банковской системы/ВВП в \%. 
Рассмотрим общее состояние и динамику макроэкономических показателей российского банковского сектора за последние шесть лет представленных в отчетности Центральным банком России (см. таблицу 1).

Таблица 1.

Макроэкономические показатели банковского сектора Российской Федераџии на начало года. [2]

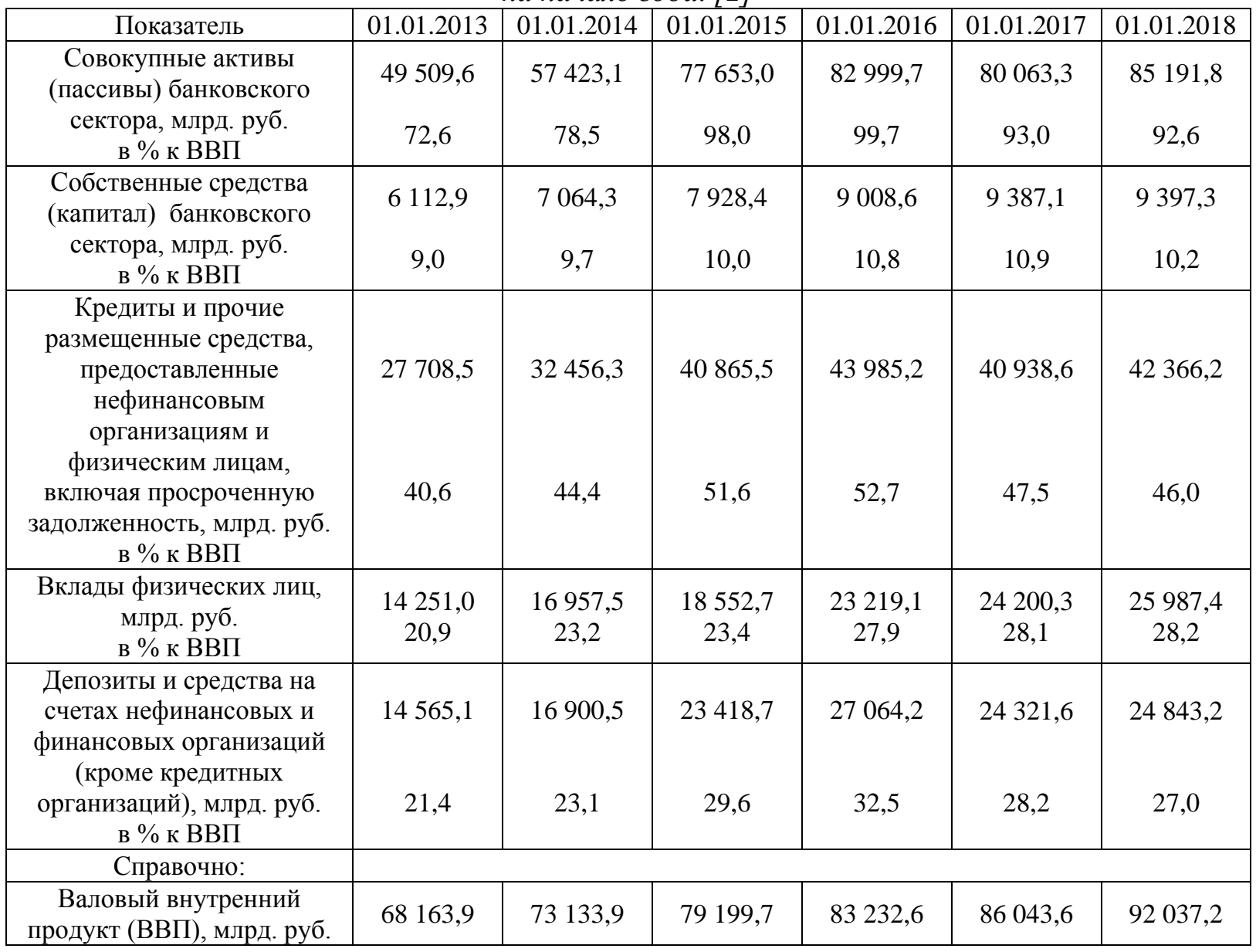

Из приведенных данных следует, что активы банковского сектора страны за истекшие шесть лет (2013-2018гг.) выросли почти в два раза от 49 509,6 млрд.руб. до 85 191,8 млрд.руб. Так положительная динамика роста наблюдается по всем основным показателям, характеризующим стабильность банковского сектора и отражающие его роль в российской экономике, которые. Рассмотрев более подробно макроэкономические показатели видим, что отношение активов банковского сектора к ВВП за рассматриваемый период с 2013 - 2018гг. в процентном соотношении возросло с 72,6 до $92,6 \%$, а отношение капитала банковского сектора к ВВП за этот же период изменилось почти на 2 пункта с 9,0 до 10,2\%. Основным источником формирования активов банковского сектора, как и ранее, являются средства на счетах клиентов, данный показатель продемонстрировал рост с 40,6 \% в 2013г. до 46,0 \% в 2018г. Так же растет и отношение вкладов населения к ВВП с 20,9 \% до 28,2\%, прирост оставляет 7,3 процентных пункта. Отношение депозитов и средств на счетах нефинансовых и финансовых организаций (кроме кредитных организаций) к ВВП прибавило 5,6 процентных пункта, что составило 27,0 \%. Кредитование экономики (предприятий и населения) с начала 2013г. до начала 2018г. возросло с 27 708,5 млрд.руб. до 42 366,2 млрд,руб., их объем к ВВП показал прирост на 5,4 процентных пункта и составил 46,0 \%. Однако удельный вес кредитов в совокупных активах банковского сектора снизился с $55,9 \%$ до 49,7 \%, что свидетельствует об опережающем темпе роста активов банковского сектора. 
Анализ динамики банковского сектора показывает, что произошел приток банковских ресурсов, которые позволяют осуществить экономическую перестройку банковского сектора под воздействием западных финансовых санкций. По оценкам Банка России, в 2017 году российская экономика продолжила адаптироваться к внешним неблагоприятным условиям, а настроение и ожидание субъектов экономики стабилизировались, при этом чувствительность к внешним неблагоприятным факторам снизилась. Прирост ВВП в 2017 году составил 1,5\% (в 2016 году отмечалось его снижение на 0,2 \%). Восстановительные процессы в динамике внутреннего спроса, как потребительского, так и инвестиционного, приобрели устойчивость.[3]

В 2017 году доступ к зарубежным источникам фондирования для российских банков был по прежнему затруднен. Данное обстоятельство стимулировало банки к более интенсивному использованию внутренних источников. На 01.01.2018 30,5\% пассивов банков формировалось за счет вкладов, а 29,2\% - за счет депозитов и средств организаций (кроме кредитных организаций) на счетах (годом ранее 30,4 и 30,2\% соответственно).[4]

В 2017 году на фоне общего роста мировой экономики и наметившейся внутренней экономической активности, запас капитала банковского сектора оценивался, как достаточный для наращивания кредитования, хотя динамика кредитования предприятий различных видов деятельности в 2017 году была разнонаправленной. Кредиты предприятиям сельского и лесного хозяйства увеличились за год на 9,2\%. Существенно возросли кредиты предприятиям, занимающимся добычей полезных ископаемых (на 24,4\%) и операциями с недвижимым имуществом, арендой и предоставлением услуг (на 27,3\%). В тоже время задолженность по кредитам, предоставленным строительным организациям, сократилась на $3,8 \%$, оптовым и розничным торговым организациям - на 3,6\%.

В 2017 году кредитными организациями получена прибыль в размере 790 млрд рублей (в 2016 году - 930 млрд рублей). Сокращение прибыли обусловлено значительным чистым доформированием резервов на возможные потери, увеличившимся за 2017 год по сравнению с 2016 годом на 769 млрд рублей, или на 39\%. Основной объем доформирования резервов на возможные потери приходился на ряд крупных банков, проходящих процедуру финансового оздоровления, в том числе с участием Банка России. В 2017 году преобладали прибыльные кредитные организации: их удельный вес по сравнению с 2016 годом увеличился с 71 до 75\%. Прибыль в сумме 1,6 трлн рублей показали 421 кредитная организация1 (в 2016 году - 1,3 трлн рублей 445 кредитных организаций соответственно). С убытками в размере 772 млрд рублей завершили год 140 кредитных организаций, а их доля в числе действующих кредитных организаций составила 25\% (в 2016 году - 178 кредитных организаций понесли 362 млрд рублей убытков, или 29\% действующих на 01.01.2017 кредитных организаций). Около 95\% величины убытков приходилось на банки, в отношении которых осуществляются меры по предупреждению банкротства. Основной вклад в финансовый результат банковского сектора внесли банки, контролируемые государством (1,0 трлн рублей), частные банки с капиталом более 1 млрд рублей (197 млрд рублей), а также банки, контролируемые нерезидентами (151 млрд рублей). [5]

Не смотря на относительно благоприятные условия, складывающиеся в рассматриваемой перспективе существует ряд проблем, с которыми приходиться сталкиваться российским кредитным организациям и которые тормозят развитие российской банковской системы это, прежде всего:

- финансовая неустойчивость российских кредитных учреждений;

- сохраняющаяся нестабильная экономическая ситуация в стране (резкие колебания курса национальной валюты, рост инфляции, безработица - всё это негативным образом сказывается на функционировании банковской системы;

— региональные и отраслевые диспропорции российской экономики; 
- недостаточный уровень капитализации российских банков, что ограничивает возможности банковской системы в сфере кредитования отечественной экономики;

- низкий уровень обеспеченности банковскими услугами большого числа российских регионов;

- ухудшение конкурентной среды на фоне огосударствления значительного количества субъектов банковского сектора.

Основными перспективами развития банковской системы Российской Федерации в современных условиях экономической нестабильности можно выделить следующие:

- совершенствование и развитие политики Банка России по рефинансированию банковской системы;

- совершенствование институциональной инфраструктуры банковского рынка;

— обеспечение доступности финансовых продуктов и услуг для населения и бизнеса;

- совершенствование и развитие банковского законодательства в вопросах, регулирования отношений, возникающих в кредитной системе;

- повышение прозрачности капитала, кредитных операции и кредитных организаций;

- развитие технологий и поддержка инноваций банковского сектора.

Выбранные направления позволят улучшить кредитную деятельность российских банков и будут способствовать развитию потенциала банковской системы в перспективе.

В заключении хотелось бы отметить, что несмотря на определенные трудности, российский банковский сектор стабильно функционирует и развивается, обеспечивая потребности как корпоративного сектора так и населения в банковских услугах, а тек же готов поддерживать возникающие предпосылки роста российской экономики.

$$
* * *
$$

1. Динамика развития банковского сектора Российской Федерации за 2011-2017гг./ В.Л. Васильев, Л.И. Гадршина, С.М. Гиниятуллина/Экономические науки № 10, 31.10.2017 [Электронный ресурс] - Режим доступа: http://novaum.ru/public/p481

2. Обзор банковского сектора Российской Федерации. Аналитические показатели. - октябрь 2018 года. -№ 192 [Электронный ресурс] - Режим доступа: http://www.cbr.ru/Collection/Collection/File/8465/obs_192.pdf

3. Годовой отчет Банка России за 2017г. [Электронный ресурс] - Режим доступа: http://www.cbr.ru/Collection/Collection/File/7796/ar_2017.pdf

4. О динамике развития банковского сектора Российской Федерации в декабре 2017 года. [Электронный pecypc] - Режим доступа: http://www.cbr.ru/Collection/Collection/File/8560/din_razv_17_12.pdf

5. Отчет о развитии банковского сектора и банковского надзора в 2018 году [Электронный ресурс] режим доступа: http://www.cbr.ru/Content/Document/File/48160/bsr_2017.pdf

\section{Саратова К.И.}

Влияние процессов глобализации на развитие российской банковской системы

Институт сферы обслужсивания и предпринимательства (филиал) ФГБОУ ВПО «Донской государственный технический университет»

(Россия, Шахты)

doi:10.18411/lj-11-2018-54

idsp: ljournal-11-2018-54

Аннотация

Статья посвящена рассмотрению особенностей экономической глобализации, процессов глобализации влияющих на банковский сектор. Анализируются тенденции глобальных изменений происходящих в банковской деятельности.

Ключевые слова: глобализация, банковская система, финансовые технологии. 